\title{
Examining the Internal Determinants of Profitability of Commercial Banks in China: A Panel Data Modeling Based Empirical Study
}

\author{
Ming-Lu Wu* \\ Division of Business and Management, United International College, Beijing Normal University-Hong Kong \\ Baptist University, 2000 Jintong Road, Tangjiawan, Zhuhai, Guangdong 519085, P. R. China \\ *Corresponding Author:Ming-Lu Wu, Division of Business and Management, United International \\ College, Beijing Normal University-Hong Kong Baptist University, 2000 Jintong Road, Tangjiawan, \\ Zhuhai, Guangdong 519085, P. R. China
}

\begin{abstract}
This study empirically examines the links to profitability of commercial banks in China of a number of internal operating and structural indicators, including non-interest income, capital adequacy ratio, nonperforming loan ratio, loan-to-deposit ratio, bank size, government ownership and foreign strategic investors' ownership of the banks. A fixed effect cross-section weighted general least-squares panel regression model is applied to analyze an unbalanced panel dataset of 26 listed banks from 2005 to 2018. We find that the popular profitability measure, return to assets, is positively related to capital adequacy ratio and non-interest income and negatively associated with non-performing loan ratio and bank size. The empirical findings suggest that ownership structure has insignificant influence on return to assets, but the proportion of foreign investors' shares has a positive relationship with another popular profitability measure, return to equity. Therefore, other profit measurements such as profit efficiency and cost efficiency could also be used in future studies to find more relationships. Based on our research findings, we suggest commercial banks in China to improve risk management and develop more non-traditional business.
\end{abstract}

Keywords:China, Commercial banks, fixed effect, internal determinants, Panel data, Profitability, Regression model.

\section{INTRODUCTION}

Before the reform of financial sector started in 1983, China was under a mono-bank system. The only financial institution in China was the People's Bank of China, which controlled 93\% of financial assets in China, andthe only form of financial asset was bank deposits(Wu et al. 2007). With China's financial sector reform in 1983, four specialized banks were re-established, including Agricultural Bank of China (ABC), Bank of China (BOC), China Construction Bank (CCB, previously called People's Bank of Construction), and Industrial and Commercial Bank of China (ICBC). In 1984, China completed the establishment of a two-tier banking system to replace its previous mono-bank system: the first tier is the central bank, People's Bank of China, and the second tier includes other banks and non-bank financial institutions (García-Herrero et al. 2006). However, problems aroused due to insufficient competition and policy burden on the four specialized banks with the nonperforming loan ratios as high as about 30 percent in the early 1990s. Through the mid-1990s, the second stage of bank reform was implemented. Specialized banks were commercialized, and regulations were improved. To enhance competition, joint-stock commercial banks (JSCBs) and private banks were encouraged by the government. Foreign banks gradually could be authorized to expand in Chinese market (Okazaki 2007).

At the end of 1990s, especially with China's WTO accession in 2001, rules, regulations, and laws started to alter again, and China promised to reducelimitations on ownership takeovers, have more fair tax treatmentsto different banks, and liberalizeloan and deposit interest rates. As a strategy of stateowned commercial bank (SOCB) reform, non-performing loans must be taken over, so four asset management companies were set up to fulfill this role in 1999(Wang 2008). Then, strategic foreign investors were introduced. For example, HSBC (Hong Kong and Shanghai Banking Corporation) acquired 19.9\% of the shares of China's Bank of Communications in 2004, Bank of America bought about 10\% of China Construction Bank's shares in 2005, and Royal Bank of Scotland bought about 
$10 \%$ of Bank of China's shares in 2005. Ultimately, Chinese government wanted state-owned commercial banks to go initial public offering (IPO). By 2010, all the four major SOCBs had been listed in the stock markets (Berger et al. 2009; Li and Liu 2019). Impressively, IPO of ICBC, which generated gross funds of as much as US\$21.9 billion, created a record of the largest amount of capital proceeds raised in the world (WSJ 2006). After China's entry into WTO in 2001, much progress has been made by the domestic banks on scales, profitability and risk resistance ability. With the full opening of China's financial markets and a great number of foreign banks into the domestic market, China's banks have to face the competition with the banks from all around the world(Huang \& Pan 2016). Comparing with other countries, a very remarkable feature of China's banking system is that concentration is much higher. Tan(2016) analyzes the data from the report published by China Banking Regulatory Commission (CBRC) for the year 2011 and he finds that total sum assets of the five largest commercial banks in China compromised for 47.3 percent of the total assets in the banking industry.

After years of financial reform since 1990s, China has formed a multi-level banking system, including state-owned commercial banks (SOCBs), city/rural commercial banks (CRCBs), joint-stock commercial banks (JSCBs) and some other financial institutions, with SOCBs taking a dominating role. The few major SOCBs have been an essential source of financing for domestic companies, especially state-owned enterprises and other institutions. In 2010, marked by the completion of Agricultural Bank of China's property right reform, all the SOCBs have finished the shareholding reform, realizing the historical transformation of state-owned banks to a diversified shareholding structure. According to the profitability index ranking of KPMG China Banking Survey Report 2017, the total net profit growth of various banks werestill quite low, especially as low as only $0.75 \%$ for the state-owned banks (KPMG2017). There were some evidences indicating that technical efficiency improvements of SOCBswere still not sufficient to keep them at the leading edge, especially relative to their huge scale (Wang \& Feng 2014). In order to suit the rising tendency of China's economic development, improving the commercial banks' profitability is exceptionally urgent.

Since China finished the ownership structure reform of its state-owned commercial banks, in general Chinese banks have made certain progresses in scales, profitability, and risk control ability along with the steady and rapid development of the overall economy. At the same time, competition among banks has gradually become more intense. For commercial banks, profitability is a key indicatorin directly reflecting their ability of risk control, sustainable development and management, andthus it is necessary for them to improve their profitability to stay an unassailable point in the competition.

In this study, we try to figure out how internal determinants affect the profitability of Chinese commercial banks. We first conduct a literature review on the relevant issues in the next section 2 . In section 3, we develop some fixed-effect models based on unbalanced panel data of 26 listed banks from 2006 to 2018, in order to examine the relationships between banks'profitability as commonly measured by ROA (return on asset) and ROE (return on equity) and their financial and operating performances as reflected in ownership structure, non-interest income, bank size, capital adequacy ratio, loan-to-deposit ratio, and so on. We summarize and analyse the modeling results in sections 4 and 5 , based on which some concluding remarksarefinally provided for improving Chinese commercial banks' profitability in the last section 6 .

\section{LiTERATURE REVIEW AND HYPOTHESES}

Commercial banks are an important type of financial institutions in the financial market, and their profitability has been studied by numerous scholars (Tobin \& Brainard 1963). Earlier researches could be traced back to a study on the relationship between profit margin and bank concentration(Short 1979). More specifically, Bourke(1989) classifies the factors affecting banks' profitability into internal and external determinants. For China, whether banks are doing a good job is significant because the development of financial market in an emerging economy is highly related to economic growth (King $\&$ Levine 1993). And we will focus more on internal factors affecting banks' profitability while more controllable by banks.

\subsection{ROA and ROE}

To identify and study the determinants of bank profitability, it is necessary to first appropriately measure profitability, which is generally done by using ROA (return on asset) or ROE (return on 
equity). Measuring the rate of returns on the assets financed by banks, ROA is more widely used than ROE as a measurement of performance of banks(Tan \& Floros 2012). Bank is a highly leveraged industry, and banking business is largely to operate on liability. The contribution of common stockholder's equity under the leverage of approximately 20 times on banks' profit is negligible, and remaining certain level of equity is to reduce the risk of bankruptcy and to meet the capital-adequacyratio(CAR) requirement (Vallascas\& Hagendorff2013; Gambacorta\& Karmakar 2016). Therefore, in this study, we will focus more on ROA as the dependent variable for bank profitability.

\subsection{Non-Interest Income}

Non-interest income, including commission fee, and trading income, has become an essential part of bank income all over the world, and China is no exception. In fact, due to the abolishment of floor and ceiling of lending and deposit rate and the development of non-bank institutions, traditional deposits accepting and loans lending business will certainly contribute lower profit ratio in Chinese commercial banks (Bian et al. 2015).

Non-traditional business can be considered as a form of diversification, which can reduce risk and improve profit forbanking sector. Scholars point out that with non-traditional business like securities and insurance underwriting, financialproduct retail, and mutual fund sales, banks will have better access to information that promotes the loan-making process (Diamond 1991). Besides, DeYoung and Roland(2001)argue that banks' income volatility could be reduced due to non-interest income activities.

The ratio of non-interest income to total revenue, denoted as NII,is used in this study to measure the variable, and we expect it to have a positive effect on profitability.

\subsection{Capital Adequacy Ratio}

The China Banking Regulatory Commission, which was established in 2003 to take up the responsibility of regulating the bank industry, publishedThe Guide for Implementing the Basel IIin 2007 (Bian et al. 2015). Issued by the Basel Committee on Banking Supervision, the Basel Accord is a set of recommendations of banking regulations. Under the regulation of the Basel Accord, banks should at least hold capital more than $8 \%$ of their weighted assets (Basel Committee on Banking Supervision2011; Sayah 2017). Capital adequacyrequirementincreases the cost of the loan business so banks will be more motivated to conduct non-traditional businessbecause these activities tend to require less capital. However, in China, the managers will be punished by the authorities if the CAR (capital adequacy ratio) requirement does not meet, and high CAR will make agency problem more serious (Huang\& Pan 2016). Therefore, we do not have any prior expectation on the impact of capital adequacy ratio on profitability.

\subsection{Non-Performing Loan Ratio}

Non-performing loan (NPL) ratio is a risk factor of the banks' capital structure. According to the levels of risks, loans are classified into five categories in China: pass, special mention, sub-standard, doubtful, and loss. The latter three are collectively referred to as non-performing loans (Huang\& Pan 2016). Higher non-performing loan ratio is certainly related to higher banking operation risk and lower profit (Berger et al. 2002; Shih 2007). Thus, the expectation of the relationship of NPL ratio and the ability of making profit of banks is negative.

\subsection{Loan-to-Deposit Ratio}

The relationship between profitability and loan-to-deposit ratio is significant, negative, and linear (Huang\& Pan 2016). Because the banks need to prepare sufficient cash for the demands of withdrawing cash by customers and daily settling accounts, loan-to-deposit ratio could not be too high. The high loan-to-deposit ratio might trigger credit catastrophe and payments catastrophe. Therefore we expect a clear negative relation between profitability and loan-to-deposit ratio.

\subsection{Bank Size}

Bank size is considered as a significant factor affecting efficiency.In the estimation process,bank size can be used as a control variable to reduce potential scale biases(Kumbhakar \& Wang 2007). Because 
of economies of scale, large banks might earn efficiency benefits (Casu \& Girardone 2006). Evanoff and Israilevich (1991)find that because of the higher-level and experienced management teams, large banks might have higher efficiency in controlling cost and get higher profits. On the other hand, Eichengreen and Gibson's(2001) book illustrate that once bank size is beyond a certain point, it may have a negative effect on bank profitability due to bureaucratic and other reasons. Especially in China, government interventions are significantly more frequent with big banks (Fadzlan2009). For the large bank, the estimated coefficients of capital decrease with the opening process. Before the access to WTO, the coefficient is at minimum become highest during the period of overall openness.However, for small banks, the coefficients gradually increasedand reached a peak before joining WTO(Lee et al. 2015). Additionally, profitability is positively influenced by capitalization and overhead expenses, while bank size hasa negative effect(Ben \& Goaied 2008).

Logarithm of total assets (LNTA) is set to be the measurement of bank size. We expect that there is a turning point before which economies of scale play a dominate role so the effect would be positive(Eichengreen \& Gibson 2001). After the point, the parameter should turn negative.

\subsection{Government Ownership}

In addition to the above five internal or operating factors, two policy or strategic factors are also considered, government ownership and foreign strategic investors' ownership in the banks. Generally, studies on the ownership of banks have illustrated that in most developing countries, foreign banks show the strongest power of making profit, but SOCBs are usually the least efficient, while private banks are in between (Berger et al. 2009). In China, the central bank uses "window guidance" to assign credit assignments to state-owned banks for industrialization and development goals. Those projects may have high social return but often with low financial return (Megginson 2005). On the other hand, there are naturally agency problems in state-ownedcorporations because ownership and management are separated (Bearle \& Means 1932). Managers may consider their political career over interest of shareholders. Privatization can help solve agency problem by hardened budget constraint and pressure of satisfying shareholders and attracting potential investors (Berger et al. 2005). Empirical evidence has shown that profitability of banks has improved after privatization (Williams \& Nguyen 2005).

We use the ratio of shares owned by the government, denoted asGov,to measure this variable and its expected effect on ROA is hypothesized to be negative.

\subsection{Foreign Strategic Investors}

Researches about the effects of foreign strategic investors on Chinese bank performance come up with mixed results. Some of them argue that foreign equity makes little difference in the profitability of banks in China (García-Herrero et al. 2009). Others find that efficiency improved owing to minority foreignownership (Berger et al. 2009). Some scholars use prudential behavior to evaluate the effect of bank's ownership and find that SOCBs are acting more prudential than before (Jia 2009).

We do not have a priori expectation on the relation between foreign investor's proportion of share and bank's profitability due to various research findings and perspectives.

\section{MODEL AND DATA}

\subsection{Proposed Model}

Based on the above literature review, we propose an empirical model to account for Chinese banks profitability using a number of internal and policy factors. It is noticed that when estimating bank profitability, we face the problem of endogeneity. It may be easier for those most profitable banks to improve profitability due to better information access or operation system that is more developed. Therefore, in this paper, in addition to the formal independent variables, 1-period lag of the dependent variable is also added into the model, making our full model expressed as follows, with definitions and notations of the variables as well as their expected effectsin profitability as hypothesized above shown in table 1: 
Examining the Internal Determinants of Profitability of Commercial Banks in China: A Panel Data Modeling Based Empirical Study

$$
\begin{aligned}
\text { Profit }_{i t} & =c+\delta \text { Profit }_{i-1}+\beta_{1} \text { NII }_{i t}+\beta_{2} \text { CAR }_{i t}+\beta_{3} \text { NPL }_{i t}+\beta_{4} \text { Loan }_{i t} \\
& +\beta_{51} \text { Size }_{i t}+\beta_{52} \text { Size }_{i t}^{2}+\beta_{6} \text { Gov }_{i t}+\beta_{7} \text { FSI }_{i t}+a_{i}+u_{i t}
\end{aligned}
$$

where $i$ and $t$ indicatebank and time, respectively, $\operatorname{Size}^{2}{ }_{\text {it }}$ is introduced to detect whether there is a turning point regarding the influence of bank size on profitability, $a_{i}$ is for the unobserved timeinvariantbank-specific factors such as location of the banks' headquarters and the categories of the banks, and $u_{i t}$ is for other unobserved errors.

Table1. Definitions and notations of variables as well as their expected effects in profitability.

\begin{tabular}{|c|c|c|c|}
\hline Variable & Notation & Measurement & Expected effect in ROA (or ROE) \\
\hline Return on asset & ROA & (Net profit)/(total assets) & \\
\hline Return on equity & ROE & (Net profit)/(shareholders' equity) & + \\
\hline Non-interest income & NII & (Non-interest income)/(gross revenues) & $?$ \\
\hline Capital adequacy ratio & CAR & (Own capital)/(total assets) & - \\
\hline Non-performing loan ratio & NPL & (Non-performing loans)/(total loans) & - \\
\hline Loan-to-deposit ratio & Loan & (Total loans)/(total deposits) & - \\
\hline Bank size & Size & Logarithm of total assets & - \\
\hline Government ownership & Gov & (government shares)/(total shares) & $?$ \\
\hline Foreign strategic investors & FSI & (foreign shares)/(total shares) & - \\
\hline
\end{tabular}

\subsection{Data}

Our sample is composed of unbalanced panel data including quarterly figures from 26 listed banks in China from 2006 to the second quarter of 2018, with a total of 50 quarters covered. The number of time series is 49 . The banks are categorized into 5 SOCBs (including Bank of Communications), 8 JSCBs, and 13 city/ruralcommercial banks (CRCBs), see Table 2 for a list of the banks studied in this paper. We have unbalanced panel because several banks (like Agriculture Bank of China) had not been listed in the initial few years and several pieces of individual banks' data were incomplete in the variables we need. In total, we have 778 observations. Most of the financial and operating data is obtained from Bank scope Database. Some information of ownership is from Yahoo Finance.

Table2. A list of the banks studied.

\begin{tabular}{|c|c|c|}
\hline Bank category & Number & Bank name \\
\hline $\begin{array}{c}\text { State-owned } \\
\text { commercial bank } \\
\text { (SOCB) }\end{array}$ & 5 & $\begin{array}{c}\text { Agricultural Bank of China (ABC).Bank of China (BOC),Bank of } \\
\text { Communications, China Construction Bank (CCB), Industrial and } \\
\text { Commercial Bank of China (ICBC). }\end{array}$ \\
\hline $\begin{array}{c}\text { Joint-stockcommercial } \\
\text { bank (JSCB) }\end{array}$ & 8 & $\begin{array}{r}\text { China Citic Bank, China Everbright Bank, China Merchants Bank, China } \\
\text { Minsheng Bank, Huaxia Bank,Industrial Bank, } \\
\text { Ping An Bank, Shanghai Pudong Development Bank. }\end{array}$ \\
\hline $\begin{array}{c}\text { City/ruralcommercial } \\
\text { bank (CRCB) }\end{array}$ & 13 & $\begin{array}{c}\text { Bank of Beijing, Bank of Chengdu, Bank of Guiyang, Bank of Hangzhou, } \\
\text { Bank of Jiangsu, Bank of Nanjing, Bankof Ningbo, Bank of Shanghai, } \\
\text { Changshu RuralCommercial Bank, Jiangyin RuralCommercial Bank, } \\
\text { Wujiang Rural Commercial Bank, Wuxi Rural Commercial Bank, } \\
\text { Zhangjiagang Rural Commercial Bank. }\end{array}$ \\
\hline
\end{tabular}

\subsection{DescriptiveStatistics}

Before the formal model estimation, according to the classification of the banks, descriptive statisticsare calculated and briefly analyzedbelow to compare the profitability as well as other indicators among different categories of banks.

Firstly, sample averages of all variables for different categories of banks are shown in Table 3a. It can be found that SOCBs had the best profitability in terms of ROA and ROE in the sample period from 2005 to 2018, but at the same time, they also suffered from the highest NPL ratio of $1.53 \%$, an overall low level. All categories of banks remained financially healthy in average with appropriate or higher CARs as required by the Basel Record. As for ownership structure, SOCBs had significantly higher shares of government as expected, and also had much higher shares of foreigners, a potential factor for SOCB's higher profitability. SOCBs also naturally had much bigger sizes in terms of total assets than other types of banks. 
Examining the Internal Determinants of Profitability of Commercial Banks in China: A Panel Data Modeling Based Empirical Study

Table3a. Sample average values of different categories of banks.

\begin{tabular}{|c|c|c|c|c|c|c|c|c|c|}
\hline & ROA & ROE & NII & CAR & NPL & Loan & Size & Gov & FSI \\
\hline Total & $1.05 \%$ & $15.61 \%$ & $20.66 \%$ & $12.23 \%$ & $1.35 \%$ & $71.22 \%$ & 48873.37 & $27.19 \%$ & $16.18 \%$ \\
\hline SOCBs & $1.19 \%$ & $18.24 \%$ & $25.42 \%$ & $13.08 \%$ & $1.53 \%$ & $69.88 \%$ & 131457.06 & $53.70 \%$ & $29.37 \%$ \\
\hline JOCBs & $1.01 \%$ & $14.09 \%$ & $22.13 \%$ & $11.03 \%$ & $1.31 \%$ & $76.88 \%$ & 28259.16 & $16.81 \%$ & $12.20 \%$ \\
\hline City Banks & $1.00 \%$ & $15.44 \%$ & $14.42 \%$ & $13.18 \%$ & $1.24 \%$ & $64.43 \%$ & 5794.56 & $18.64 \%$ & $10.27 \%$ \\
\hline
\end{tabular}

Table3b. Cross correlation matrix.

\begin{tabular}{|c|c|c|c|c|c|c|c|c|c|}
\hline & ROA & ROE & NII & CAR & NPL & Loan & Size & Gov & FSI \\
\hline ROA & 1.0000 & & & & & & & & \\
\hline ROE & 0.1410 & 1.0000 & & & & & & & \\
\hline NII & 0.1458 & 0.0386 & 1.0000 & & & & & & \\
\hline CAR & 0.3176 & 0.1798 & 0.0993 & 1.0000 & & & & & \\
\hline NPL & -0.3526 & -0.2950 & -0.0014 & -0.1938 & 1.0000 & & & & \\
\hline Loan & -0.1757 & 0.0006 & 0.4011 & -0.1423 & 0.0564 & 1.0000 & & & \\
\hline Size & 0.3222 & 0.0429 & 0.6448 & 0.0125 & -0.0123 & 0.2373 & 1.0000 & & \\
\hline Gov & 0.2295 & -0.0275 & 0.1691 & 0.1448 & 0.0954 & -0.1488 & 0.4556 & 1.0000 & \\
\hline FSI & 0.3353 & 0.0525 & 0.2024 & 0.1931 & -0.0296 & 0.0768 & 0.4502 & 0.2563 & 1.0000 \\
\hline
\end{tabular}

Secondly, correlations between each pair of the modeling variables are summarized in Table $3 \mathrm{~b}$. It can be seen that, for each independent variable, its correlation with ROA is much stronger than with ROE, which supports the choice of ROA, not ROE, as the dependent variable for measuring banks'profitability. It is also observed that, except for a few relatively strong correlations (0.40-0.65; between NII and Loan, and between Size and each of NII, Gov and FSI), correlations between each pair of independent variables are quite weak (below 0.26), indicating that multi-colinearity among the model's independent variables is not a big concern in the sample data.

\section{Modeling Estimation}

\subsection{Panel Data Model or Pooled Cross-Sectional Model}

The software to be used for estimating our model is Eviews 10, a well-known powerful package for analyzing cross-sectional data, time series data, and the combined panel data as in our study. First, to determine whether panel data model or pooled cross-sectional ordinary least squares (OLS) should be used, redundantfixed effect test is conducted. The results are shown in Table 4, where p-values of both cross-section Fand Chi-square is 0.0000 , so the null hypothesis that pooled (cross-sectional) OLS is correct is rejected. Therefore, panel data model should be used.

Table4. Redundant fixed effects tests

\begin{tabular}{|c|c|c|c|}
\hline Effects Tst & Statistic & d.f. & Prob. \\
\hline Cross-section F & 5.310730 & $(25,717)$ & 0.0000 \\
\hline Cross-section Chi-square & 127.755633 & 25 & 0.0000 \\
\hline
\end{tabular}

\subsection{Fixed Effect or Random Effect}

In order to choose between random effect and fixed effect panel data models, Hausmantest is conducted. The results are shown in Table 5. The null hypothesis of random effect is rejected, so we adopt the fixed effect model. In fact, it is the same as we expected. Different categories of banks in China have very different corporate governance and they face different policies from government, so we believe that bank-specific individual factors should have considerable correlations with banks' profitablity.

Table5. Hausman test

\begin{tabular}{|c|c|c|c|}
\hline Test Summary & Chi-Sq. Statistic & Chi-Sq. d.f. & Prob. \\
\hline Cross-section random & 130.394019 & 9 & 0.0000 \\
\hline
\end{tabular}

We also expect heteroscedasticity among cross-sections, still because there is much of difference of corporate governance between banks, so we test heteroscedasticity by running a regression of the square of residual of the fixed effect model. The probability of F-statistic is 0.0000 , which illustrates the existence of heteroscedasticity among different banks. In order to make sure that our model produces errors which will could be viewed as a stationary process, cross-section weighted general least squares (GLS) method is used to estimate our proposed panel data model.

International Journal of Managerial Studies and Research (IJMSR) Page | 6 
Examining the Internal Determinants of Profitability of Commercial Banks in China: A Panel Data Modeling Based Empirical Study

Table6.The results of parameter estimation

\begin{tabular}{|c|c|c|c|c|}
\hline \multirow{2}{*}{ Independent variables } & \multicolumn{2}{|c|}{ ROA } & \multicolumn{2}{|c|}{$\mathrm{ROE}$} \\
\hline & Coefficient & t-statistic & Coefficient & t-statistic \\
\hline ROA(-1)or ROE(-1) & $0.5047^{* * *}$ & 17.40 & -0.0016 & -0.80 \\
\hline Constant & $0.0339^{* *}$ & 3.39 & $0.7035^{* *}$ & 3.93 \\
\hline NII & $0.0027^{* *}$ & 2.71 & 0.0063 & 0.35 \\
\hline CAR & $0.0088^{* * *}$ & 2.76 & $-0.5695^{* *}$ & -9.89 \\
\hline NPL & $-0.0569^{* *}$ & -6.33 & $-2.0037^{* *}$ & -10.92 \\
\hline Loan & $-0.0028^{* *}$ & -2.92 & $-0.1395^{* *}$ & -7.86 \\
\hline Size & $-0.0032^{* * *}$ & -2.33 & -0.0219 & -0.89 \\
\hline Size $^{2}$ & $0.0001^{*}$ & 1.77 & -0.0001 & -0.15 \\
\hline Gov & -0.0003 & -0.84 & -0.0044 & -0.69 \\
\hline FSI & 0.0010 & 1.21 & $0.0968^{* * *}$ & 5.51 \\
\hline R-squared & \multicolumn{2}{|c|}{0.7493} & \multicolumn{2}{|c|}{0.7985} \\
\hline Adjusted R-squared & \multicolumn{2}{|c|}{0.7374} & \multicolumn{2}{|c|}{0.7889} \\
\hline F-statistic & \multicolumn{2}{|c|}{$63.0164^{* *}$} & \multicolumn{2}{|c|}{$83.5618^{* * *}$} \\
\hline Durbin-Watson stat & \multicolumn{2}{|c|}{2.1365} & \multicolumn{2}{|c|}{1.3139} \\
\hline \multicolumn{5}{|c|}{ *. significant at the 0.1 level (two sides) } \\
\hline \multicolumn{5}{|c|}{ **. significant at the 0.05 level (two sides) } \\
\hline
\end{tabular}

\subsection{EstimationResults}

Estimation results of both the ROA and ROE models are shown in Table 6. Higher-than-0.73 adjusted $\mathrm{R}$-squared shows enough goodness of fitting. F-statistic is higherthan 63, indicating high significance of the model's overall estimation results. In terms of overall fitting, the model with ROE as the dependent variable is better because of higher adjusted R-square andF-statistic. However, as stated above, ROA is more suitable to measure banks' performance, and using ROA will make it more convenient to compare our results with existing literature. Also, there are more independent variables which are significant in explaining ROA than ROE, except that foreigner investor's share is found significantly related to ROE, not ROA. Therefore, we prefer the ROA model over the ROE model, and most of our discussions will be mainly focused on the ROA model. As for the DW-statistic, it was very low before adding the 1-period lagged term of the dependent variable, indicating strong firstorder serial correlation in the model. After adding the 1-period lagged term of the dependent variable, DW-statistic of the ROA model is significantly improved to a totally acceptable level of 2.14, indicating no more first-order serial correlation in the model, although the ROE model still has a relatively low DW-statistic of 1.31, still indicating considerable first-order serial correlation in the model, which is another reason for our preference of the ROA over the ROE model.

\section{Discussions}

\subsection{Non-Interest Income}

Under the 5\% significance level, the relationship among non-interest income and profitability is positive, which is identical with our preconception.

In the context of the revenue structure of the Chinese banks in the past decade, the interest income holds the main statues, taking account of $80 \%$ of the sales revenue. However recently, the proportion of the non-interest income has enlarged among the sales revenue yearly. At present, the largest percentage of the non-interest income of a bank is up to $40 \%$ (Bian, Wang, \& Sun, 2015). In recent years, Chinese banks have begun to broaden the invested capital on non-interest income, which is a high-return-rate, substantial and safe operation. For the investor, the rate of increase in non-interest income of the bank is absolutely vital. Not only can it lower the risk, but also it is the main driving power of the bank's performance. On the one hand, the increase of the non-interest income will stimulate the original profit margin, as well as increase the operation revenue. On the other hand, from the perspective of the bank's structure, the revenue structure will get improved and optimized. It will become the profit growth point for the bank, diversifying the revenue structure at the same time. Besides, the primary source of the non-interest income is Off-Balance Sheet Activities (OBS) and intermediary business, which is less affected by national macroeconomic policies. In this situation, the increase of non-interest income will be more stable. Therefore, to a certain extent, the increase of the non-interest income will stabilize the performance of the banks. 


\subsection{Capital Adequacy Ratio}

We do not have an expectation on the sign of the coefficient of CAR. From our data, we found that the relationship between capital adequacy ratio and ROA is positive.The correlation between capital adequacy ratio and non-performing ratio is negative.

The capital adequacy ratio is a momentous standard to the operation and developmentof the financial institutions. Besides, it is aimed at controlling the undue expansion of risky assets, protecting the interest of the creditors and depositors. The problem of non-performing asset has been crucial in promoting the market competitiveness and accelerating the speed of development. The main reasons for the low capital adequacy ratio are high non-performing loan ratio, which cause the high risk of the capital. The high risk weight of non-performing loans will cause the risky assets relatively large, so the capital adequacy ratio is low. The capital adequacy ratio will be affected by the large amount of non-performing assets, increasing the credit risks of the banks.

\subsection{Non-Performing Loan Ratio}

Under the 5\% significance level, non-performing loan ratio and ROA are negatively related. The nonperforming loan ratio is one of the most important indexes to evaluate the security status of the credit assets for financial institutions, which will affect banks' performance and stability. The nonperforming loan ratio is regarded as the primary element of inefficiency of the state-owned banks in China. The large presence of non-performing loan ratio during a financial crisis, which means the longer delay of the financial rescue from the financial sectors, will lead to the lengthier and largerscale economic recession. That is, the bank should control the non-performing loan ratio.

\subsection{Loan-To-Deposit Ratio}

We get the result that the correlation between loan-to-deposit ratio and ROA is negative under the 5\% significance level, which is the same as we expected.

The loan-to-deposit ratio is one of the indicators to measure the liquidity risk for the banks. From the perspective of the bank's anti-risk preference, the loan-to-deposit should not be too high. The banks need to reserve a certain amount of cash deposit reserve for coping with the cash withdrawal and settlement of the customers. The excessive loan-to-deposit ratio will result in the insufficiency of fund so the payment crisis will appear.

\subsection{Bank Size}

The parameter of the quadratic form of total asset in the ROA model is positive and it is opposite with our preconception. ROE model, however, has a negative parameter with the quadratic form of total asset, but it is not significant. Our preconception about bank size is increasing firstly and then decreasing. The result shows a curve with an upward opening, which decrease firstly and then increase. It is unreasonable from the perspective of law of diminishing return, but according to the descriptive data, it can be found that it is the big state-owned banks who have the highest ROA. This may come down to China's special national conditions.

In China, larger bank size means higher level of the government intervention and the Big Four is the best example. Although SOCBs are facing higher policy burden, they are also strongly supported by the government including fund injection and bad assets taken over. It is obvious that SOCBs are in a dominant position in the relevant markets and they tend to abuse this position. A typical performance is arbitrary charges including account management fees, debit card annual fees, and cross-bank inquiry fees(Ghosh 2016; Tan 2016). On the other hand, SOCBs have way more accumulated operation experience. They have more abundant products and more connections with big companies, and that also explains why SOCBs have higher profitability.

\subsection{Government Ownership}

The result does not follow our assumption. Proportion of government share has no significant relation between neither ROA or ROE. On the one hand, in order to stabilize the development of economic growth, the government will set the government control on the state-owned banks, which will reduce the risk-taking level and yield rate. This is the situation in developing countries. On the other hand, with the high percentage of the government shares, the commercial banks have the larger pressure 
from the government to issue loans to rescue the economy during the period of economic recession, so the choices for promoting the benefits will be impaired. We believe these two perspectives can explain the insignificant relation between government's share with ROA and ROE.

The privatization reform among the Big Four runs smoothly, which means the decrease of the distribution of government shares. Currently, the Big Four has the lowest profit efficiency, compared with the foreign banks and the major differences are from the allotment of shares. The authorities recently found that the strategic foreign investors have a positive effect on cost control, enhancing the corporate governance of the banks, and operational technology(China Banking Regulatory Commission 2005).

\subsection{Foreign Strategic Investors}

Our regression result shows no relation between foreign investors' share and ROA, but it has a significant positive relation with ROE. This outcome shows that foreign investors are more concerned about shareholder's interest, but their influence should be considered very limited. Foreign strategic investors promised to supply technical support to China's banks in their agreements. Their help is reflected in non-traditional business. We found obvious positive relation between foreigner's share and non-interest income. Some researchers found that when foreign investors assign directors orsenior managers into China's banks, non-interest income will have a bigger share(Xu, 2011). Other than that, foreign managers are also found improving prudentialbehavior which can make risk lower and efficiency higher, so it helps with both short-term operation and long-term improvement(Jia, 2009).

\section{CONCluding Remarks}

Like many other industries, the banking sector of China is frequently under direct or indirect government intervention. Different categories of banks face different degree of policy burden and restriction from the government, which can partly be reflected by their operating indicators and ownership structures. This paper uses 778 observations containing 26 banks and 49 quarterly periods from 2005 to 2018 to analyze the internal profit determinants of commercial banks in China.The empirical findings show that in China, SOCBs are the most profitable in terms of ROA and ROE, although this result may come from our limitation of measurement of profitability. Our panel data modeling output shows that capital-adequacy ratio and non-interest income are positively related to ROA, implying that more strict risk control and creation of non-traditional business are helpful for banks' profit. Moreover, non-performing loan ratio and loan-to-deposit ratio have negative effects in ROA, which is reasonable due to banks'profit pattern. The influence of bank size in ROA is firstly decreasing and then increasing after a certain turning point, which could be due to the dominant position of big SOCBs in the financial market. To our surprise, ownership structure shows insignificant relationship with profitability except that foreign share is positively related to ROE. Therefore, other measurements of the dependent profitability variable may be necessary in further study to examine the importance of ownership structure.

\subsection{Recommendations}

Some measurements need to be taken about promoting the capital adequacy especially for the stateowned banks. Decreasing the debt risk are necessary to be regarded as the urgent affairs so the government needs to establish the reasonable mechanisms of risk management, developing the capability associated with risk prohibition. According to the requirement of Basel New Capital Accord, the banks are encouraged to transform into modern risk management mechanisms. Additionally, the banks can set up the internal risk evaluation agency, which can offer significant gist for reference. Meanwhile, it is necessary to consider the risk management first. Some risk officers with the independent business line need to be set, who are directly responsible to the chairman. Being contrary to reality, it is better for the risk officers to report to the chairman of the board directly, or even to the shareholders' meeting directly, which can handle the problems in time. It is fundamental for the banks to cut down the non-performing loan ratio by building the loan assessment system and development comprehensive quality of the employees.

For the non-interest income, the types of it need to be diversified and innovated with the processing business as its main business and supplemented by consulting business. As the most basic one, the processing business requires the general equipment and technology, simple procedure, and ordinary employees. In addition, in the area of consulting business, introducing some employees with profound

\footnotetext{
International Journal of Managerial Studies and Research (IJMSR) Page 9
} 
professional knowledge, strong comprehensive ability and sophisticated operation technique is quite urgent. The banks can start some business like corporate finance consulting and personal financial consulting first while the condition of the employees is not ready. Finally yet importantly, the transaction business can develop deeper as well, with the considerable income. The banks can try to operate on stock-jobbing, asset securitization and risky asset trading properly. The mode of business also can be innovated. The banks can make full use of the relation between customers from the traditional business. In the process of handling corporate and personal deposits, banks can promote credit cards, commercial debts, and various consulting services to familiarize the customers. In the process of individual loan issuance, banks have greater influence and initiative to promote noninterest income business.

Foreign strategic investors have the positive effect on enhancing the core competitiveness and innovation capability, expanding the market share and committing to long-term investment so the share of the foreigner strategic investors of the banks can be enlarged properly. What's more, foreign strategic investors can help to promote the prudential regulation, strengthen the internal management and carry out the warning and control of the risk.

\subsection{Limitations and Future Research Directions}

Just as many empirical studies, this paper is not without limitations. The first is incompleteness of our data. Our unbalanced panel has only half of the number of observation as a balanced panel should be. Some city banks' data are missing. This problem may affect the significance of our research, and more effort should be made to collect more complete data from more Chinese commercial banks to explore their profitability patterns. Secondly, ROA and ROE are just very simple, although popular, methods of measuring banks'profitability,which may be a reason that some of our modeling results are different with our expected hypotheses, e.g., the results with bank size and ownership structure. It is noticed that a great amount of professional and academic papers have been using banking efficiency derived from DEA (data envelopment analysis) method to measure banks' performance (Matthews 2013;An et al. 2015; Wanke et al. 2016; Zhou \& Zhu 2017; Ouenniche \& Carrales2018). With efficiency as the dependent variable, the modeling results are likely to be closer to the theory. Moreover, other than internal determination, external environment also has influence on banks' operation. As a vital part of financial market, banks' profitability should be related closely with the general economic environment. Therefore, in future studies, external economic indicators like growth of GDP, CPI, and stock market index could be included.

\section{ACKNOWLEDGEMENT}

This research was supported by a research grant (R201832) from United International College, Beijing Normal University-Hong Kong Baptist University.

\section{REFERENCES}

[1] An, Q., Chen, H., Wu, J., \& Liang, L. (2015). Measuring slacks-based efficiency for commercial banks in China by using a two-stage DEA model with undesirable output. Annals of Operations Research, 235(1), 13-35.

[2] Athanasoglou, P. P., Brissimis, S. N., \& Delis, M. D. (2005). Bank-specific, industry-specific and macroeconomic determinants of bank profitability. Athens: Bank of Greece.

[3] Basel Committee on Banking Supervision (2011).Core principles for effective banking supervision. BIS (Bank for International Settlements) Consultative Document, December 2011, https://www.bis.org/publ/bcbs213.pdf.

[4] Bearle, J. A., \& Means, G. C. (1932). The Modern Corporation and Private Property. New York: Macmillan.

[5] Ben, N. S., \& Goaied, M. (2008). The determinants of commercial bank interest margin and profitability: evidence from Tunisia. Frontiers in Finance and Economics, 106(1), 106-136.

[6] Berger, A. N., Clarke, G. G., Cull, R., Klapper, L., \& Udell, G. F. (2005). Corporate governance and bank performance: a joint analysis of the static, selection, and dynamic effects of domestic, foreign, and state ownership. Journal of Banking \& Finance, 29, 2197-2221.

[7] Berger, A. N., Hasan, I., \& Zhou, M. (2009). Bank ownership and efficiency in China: What will happen in the world's largest nation? Journal of Banking \& Finance, 33(1), 113-130.

[8] Berger, L. W., Nast, G. R., \& Raubach, C. (2002). Fixing Asia's bad-debt mess: A banking crisis crippled Asia's economies in 1997 -- A bad-debt crisis threatens to do so again unless governments and banks crack 
Examining the Internal Determinants of Profitability of Commercial Banks in China: A Panel Data Modeling Based Empirical Study

down on nonperforming loans. The McKinsey Quarterly, 12, 139.

[9] Bian, W.-L., Wang, X.-N., \& Sun, Q.-X. (2015). Non-interest income, profit, and risk efficiencies: Evidence from commercial banks in China. Asia-Pacific Journal of Financial Studies, 44, 762-782.

[10] Bourke, P. (1989). Concentration and other determinants of bank profitability in Europe, North America and Australia. Journal of Banking \& Finance, 13(1), 65-79.

[11] Casu, B., \& Girardone, C. (2006). Bank competition, concentration and efficiency in the single European market. Manchester School, 74, 441-468.

[12] China Banking Regulatory Commission. (2005). 2015 Annual Report. http://www.cbrc.gov.cn/chinese/files/2016/6C1DEC063D6442B289B7C24F662D2E52.pdf

[13] DeYoung, R., \& Roland, K. P. (2001). Product mix and earnings volatility at commercial banks: Evidence from a degree of total leverage model. Journal of Financial Intermediation, 10, 54-84.

[14] Diamond, D. (1991). Monitoring and reputation: The choice between bank loans and directly placed debt. General Information, 99, 689-721.

[15] Eichengreen, B., \& Gibson, H. D. (2001). Greek banking at the dawn of the new. London: Centre for Economic Policy Research (CEPR).

[16] Evanoff, D. D., \& Israilevich, P. R. (1991). Regional differences in bank efficiency and technology. Annals of Regional Science, 25, 41-54.

[17] Fadzlan, S. (2009). Determinants of bank profitability in a developing economy: Emprical evidence from the China banking sector. Journal of Asia-Pacific Business, 10(4), 281-307.

[18] Gambacorta, L.,\& Karmakar, S. (2016). Leverage and risk weighted capital requirements. BIS Working Papers (Bank for International Settlements), No. 586 (September).

[19] García-Herrero, A., Gavilá, S., \& Santabárbara, D. (2006). China's banking reform: An assessment of its evolution and possible impact. CESifo Economic Studies, 52(2), 304-363, doi:10.1093/cesifo/ifl006.

[20] García-Herrero, A., Gavilá, S., \& Santabárbara, D. (2009). What explains the low profitability of Chinese banks? Journal of Banking \& Finance, 33(11), 2080-2092.

[21] Ghosh, A. (2016). Banking sector globalization and bank performance: A comparative analysis of low income countries with emerging markets and advanced economies.Review of Development Finance, 6(1), 58-70.

[22] Huang, Z., \& Pan, H. (2016). A study on the impact of capital structure of China's listed commercial banks on profitability. Management \& Engineering, 22, 65-71.

[23] Jia, C. (2009). The effect of ownership on the prudential behavior of banks: The case of China. Journal of Banking and Finance, 33(1), 77-87.

[24] King, R., \& Levine, R. (1993). Finance and growth: Schumpeter might be right. Quarterly Journal of Economics, 108(3), 717-737.

[25] KPMG. (2017). Mainland China Banking Survey 2017. KPMG, August 2017 , https://assets.kpmg/content/dam/kpmg/cn/pdf/en/2017/08/2017-mainland-china-banking-survey.pdf

[26] Kumbhakar, S., \& Wang, D. (2007). Economic reforms, efficiency and productivity in Chinese banking. Journal of Regulatory Economics, 32, 105-129.

[27] Lee, C. C., Ning, S. L., \& Lee, C. C. (2015). How does bank capital affect bank profitability and risk? Evidence from China's WTO accession. China \& World Economy, 23(4),19-39.

[28] Li, J. \& Liu, M.-H. (2019). Interest rate liberalization and pass-throughof monetary policy rate to bank lendingrates in China. Frontiers of BusinessResearch in China, 13(8), https://doi.org/10.1186/s11782-0190056-z.

[29] Liu, H., \& Wilson, J. (2009). The profitability of banks in Japan: The road to recovery.Working Paper Series (Cass Business School, City University London), WP 06/09 (November).

[30] Matthews, K. (2013). Risk management and managerial efficiency in Chinese banks: A network DEA framework. Omega, 41(2), 207-215.

[31] Megginson, L. W. (2005). The economics of bank privatization. Journal of Banking \& Finance, 29(8-9), 1931-1980.

[32] MSCI (2018). The Global Industry Classification Standard (GICS®). MSCI, https://www.msci.com/gics.

[33] Okazaki, K. (2007).Banking system reform in China: The challenges of moving toward a market-oriented economy. RAND Corporation(www.rand.org).

[34] Ouenniche, J.,\& Carrales, S. (2018). Assessing efficiency profiles of UK commercial banks: A DEA analysis with regression-based feedback. Annals of Operations Research,266(1-2), 551-587. 
[35] Sayah, M. (2017). Understanding some new Basel III implementation issues for Lebanese commercial banks. Business administration, Université de Lyon, https://tel.archives-ouvertes.fr/tel-01684871.

[36] Shih, V.(2007). Partial reform equilibrium, Chinese style: Political incentives and reform stagnation in Chinese financial policies. Comparative Political Studies, 40(10), 1238-1262, https://doi.org/10.1177/0010414006290107.

[37] Short, B. K. (1979). The relation between commercial bank profit rates and banking concentration in Canada, Western Europe, and Japan. Journal of Banking and Finance, 3(3), 209-219.

[38] Tan, Y. (2016). The impacts of risk and competition on bank profitability in China. Journal of International Financial Markets Institutions \& Money, 40(January), 85-110.

[39] Tan, Y., \& Floros, C. (2012). Bank profitability and inflation:the case of China. Journal of Economic Studies, 39(6), 675-696.

[40] Tobin, J., \& Brainard, W. C. (1963). Financial intermediaries and the effectiveness of monetary controls. The American Economic Review, 53(2), 383-400.

[41] Vallascas, F.,\& Hagendorff, J. (2013). The risk sensitivity of capital requirements: Evidence from an international sample of large banks. Review of Finance, 17, 1947-988.

[42] Wang, L. (2008). Property Right Reform of State-Owned Commecial Banks in China.Beijing: Social Sciences Press.

[43] Wang, Q., \& Feng, X. (2014). Does property rights reform improve the efficiency of China's state-owned banks? China \& World Economy, 22(4), 1-20.

[44] Wanke, P., Barros, C. P., \& Emrouznejad, A. (2016). Assessing productive efficiency of banks using integrated fuzzy-DEA and bootstrapping: A case of Mozambican banks. European Journal of Operational Research, 249(1), 378-389.

[45] Williams, J., \& Nguyen, N. (2005). Financial liberalization, crisis, and restructuring: A comparative study of bank performance and bank governance in South East Asia. Journal of Banking \& Finance, 29, 21192154.

[46] WSJ (2006). ICBC Completes World's Biggest IPO.The Wall Street Journal, 20 October.

[47] Wu, H.-L., Chen, C.- H., \& Shiu, F.- Y. (2007). The impact of financial development and bank characteristics on the operational performance of commercial banks in the Chinese transitional economy. Journal of Economic Studies, 34(5), 401-414.

[48] Wu, Q. (2016). Profitability analysis of Pudong Development Bank. Financial Innovation, 8, $123-124$.

[49] Xu, Y. (2011). Towards a more accurate measure of foreign bank entry and its Impact on domestic banking performance: The case of China. Journal of Banking \& Finance, 35(4), 886-901.

[50] Zhou, L.,\& Zhu, S. (2017). Research on the efficiency of Chinese commercial banks based on undesirable output and super-SBM DEA model. Journal of Mathematical Finance,7(1), 102-120.

\section{AUTHOR's BIOGRAPHY}

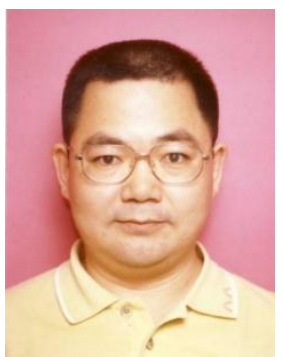

Dr. Ming-Lu Wu received his M.Sc. degree in operations research in 1986 and $\mathrm{Ph} . D$. degree in mathematical statistics in 1994 respectively, both from the famous Chinese Academy of Sciences (Beijing). He has more than 30 years' of fruitful research and teaching experiences in economic analysis and forecasting, performance and productivity assessments, multi-criteria decision analysis, (statistical) quality management, consumer satisfaction and structural equation modeling, applied mathematics and statistics, and quantitative finance and actuarial science in Ministry of Science and Technology of China, City University of Hong Kong, University of South Australia, and currently as an Associate Professor in United International College (of Beijing Normal University-Hong Kong Baptist University).

Citation:Ming-Lu Wu. "Examining the Internal Determinants of Profitability of Commercial Banks in China: A Panel Data Modeling Based Empirical Study" International Journal of Managerial Studies and Research (IJMSR), vol 8, no. 3, 2020, pp. 1-12. doi: http:// dx.doi.org/10.20431/2349-0349.0803001.

Copyright: $\odot 2020$ Authors. This is an open-access article distributed under the terms of the Creative Commons Attribution License, which permits unrestricted use, distribution, and reproduction in any medium, provided the original author and source are credited. 